\title{
Ternary $\mathrm{Ag} / \mathrm{AgCl} / \mathrm{BiOIO}_{3}$ composites for enhanced visible-light-driven photocatalysis
}

\author{
Ting Xiong a, Huijun Zhang a, Yuxin Zhang b, Fan Dong a,* \\ a Chongqing Key Laboratory of Catalysis and Functional Organic Molecules, College of Environment and Resources, Chongqing Technology and Business \\ University, Chongqing 400067, China \\ ${ }^{\mathrm{b}}$ College of Materials Science and Engineering, Chongqing University, Chongqing 400044, China
}

\section{A R T I C L E I N F O}

Article history:

Received 21 August 2015

Accepted 13 September 2015

Published 20 December 2015

Keywords:

$\mathrm{Ag} / \mathrm{AgCl} / \mathrm{BiOIO}_{3}$

Ternary composite

Visible-light photocatalysis

Nitrogen oxide removal

Charge seperation

\author{
A B S T R A C T
}

Ternary $\mathrm{Ag} / \mathrm{AgCl} / \mathrm{BiOIO}_{3}$ composite photocatalysts are prepared by a facile method. Enhanced visible-light absorption and charge carrier separation are achieved after the introduction of $\mathrm{Ag} / \mathrm{AgCl}$ particles into $\mathrm{BiOIO}_{3}$ systems, as revealed by ultraviolet-visible diffuse-reflectance spectrometry, photocurrent response and electrochemical impedance spectroscopy. The $\mathrm{Ag} / \mathrm{AgCl} / \mathrm{BiOIO}_{3} \mathrm{compo}^{-}$ sites are applied to the visible-light photocatalytic oxidization of NO in air and exhibit an enhanced activity for $\mathrm{NO}$ removal in comparison with $\mathrm{Ag} / \mathrm{AgCl}$ and pure $\mathrm{BiOIO}_{3}$. A possible photocatalytic mechanism for $\mathrm{Ag} / \mathrm{AgCl} / \mathrm{BiOIO}_{3}$ is proposed, which is related to the surface plasmon resonance effects of Ag metal and the effective carrier separation ability of $\mathrm{BiOIO}_{3}$. This work provides insight into the design and preparation of $\mathrm{BiOIO}_{3}$-based materials with enhanced visible-light photocatalysis ability.

(C) 2015, Dalian Institute of Chemical Physics, Chinese Academy of Sciences. Published by Elsevier B.V. All rights reserved.

\section{Introduction}

Semiconductor photocatalysts, used for solar-energy conversion with application in environment and energy, have attracted extensive interest [1-3]. The search for highly efficient photocatalysts is the key to practical applications. The photocatalysis efficiency is mainly associated with the optical absorption, charge separation, and interfacial transfer [4-7]. Generally, a single component photocatalyst suffers from poor visible-light absorption or/and a high charge recombination rate. To address these major problems, much effort has been devoted to investigating strategies such as doping, deposition, grafting, surface sensitization, and heterostructure construction [8-12].

Constructing heterostructures is not only appealing in en- hancing the performance of the individual photocatalysts but also for introducing some novel and unique properties [13-16]. Recently, Ag/AgX (X = Cl, I, Br) have been suggested as efficient cocatalysts to construct ternary photocatalysts and improve the photocatalytic performance [17-19]. Especially, Ag/AgCl has been successfully applied to boost the photocatalytic activity of semiconductors with narrow or wide bandgaps. For instance, $\mathrm{Yu}$ et al. [20] prepared $\mathrm{Ag} / \mathrm{AgCl} / \mathrm{TiO}_{2}$ nanotube array and found that it exhibited a high visible-light photocatalytic activity for the degradation of methyl orange. Zhang et al. [21] reported $\mathrm{Ag} / \mathrm{AgCl} / \mathrm{Bi}_{2} \mathrm{MoO}_{6}$ composites with superior visible-light photocatalytic activities in the decomposition of rhodamine B solution. $\mathrm{Xu}$ et al. [22] found that $\mathrm{Ag} / \mathrm{AgCl} / \mathrm{WO}_{3}$ hollow spheres displayed excellent visible-light-response photocatalytic activity and recycling ability for the degradation of

\footnotetext{
* Corresponding author. Tel/Fax: +86-23-62769785-605; E-mail: dfctbu@126.com

This work is supported by the National Natural Science Foundation of China (51478070, 51108487) and the Science and Technology Project from Chongqing Education Commission (KJ1400617).
}

DOI: 10.1016/S1872-2067(15)60980-9 | http://www.sciencedirect.com/science/journal/18722067 | Chin. J. Catal., Vol. 36, No. 12, December 2015 
4-chlorophenol.

Various types of semiconductor photocatalysts have been developed, including monometal oxides, metal sulfides, and composite oxides [23-26]. Much attention has been given to Bi-based photocatalysts, such as $\mathrm{Bi}_{2} \mathrm{O}_{3}, \mathrm{Bi}_{2} \mathrm{WO}_{6}, \mathrm{BiOCl}, \mathrm{Bi}_{2} \mathrm{O}_{2} \mathrm{CO}_{3}$, $\mathrm{BiVO}_{4}$, and $\mathrm{NaBiO}_{3}$, for hydrogen production and environmental remediation [27-31]. Recently, nanostructured $\mathrm{BiOIO}_{3}$ possessing two lone-pair cations and displaying an Aurivillius-type $(\mathrm{BiO})_{2}{ }^{2+}$ layer has been reported to exhibit high photocatalytic activity [32-34]. Unfortunately, owing to its large bandgap, it can be only activated by ultraviolet light, which impedes its application. Some efforts have been made for the enhancement of the photocatalytic ability of $\mathrm{BiOIO}_{3}$ through heterojunction construction, including the synthesis of $\mathrm{BiOIO}_{3} / \mathrm{Bi}_{2} \mathrm{WO}_{6}, \mathrm{BiOIO}_{3} /$ g- $\mathrm{C}_{3} \mathrm{~N}_{4}, \mathrm{BiOIO}_{3} / \mathrm{RGO}$, and $\mathrm{BiOIO}_{3} / \mathrm{BiOI}$ [35-38]. Nonetheless, the photocatalytic activity of $\mathrm{BiOIO}_{3}$ is far from efficient for practical applications, and it is highly desirable to improve the photocatalysis efficiency. To our knowledge, using $\mathrm{Ag} / \mathrm{AgCl}$ as cocatalyst to create ternary $\mathrm{BiOIO}_{3}$-based composites with enhanced photocatalytic performance is not reported yet.

Herein, we prepared ternary $\mathrm{Ag} / \mathrm{AgCl} / \mathrm{BiOIO}_{3}$ composites by a two-step method. The as-prepared composites showed enhanced visible-light absorption owing to the surface plasmon resonance of metallic Ag. Strong interfacial interactions existed in these components, and the significantly improved charge separation and migration in $\mathrm{Ag} / \mathrm{AgCl} / \mathrm{BiOIO}_{3}$ composites were demonstrated by the photocurrent response and electrochemical impedance spectroscopy. The $\mathrm{Ag} / \mathrm{AgCl} / \mathrm{BiOIO}_{3}$ composites showed higher visible-light photocatalytic performance than the $\mathrm{Ag} / \mathrm{AgCl}$ and $\mathrm{BiOIO}_{3}$ for the removal of NO. The possible photocatalytic mechanism responsible for the improved photocatalytic performance was also proposed. The outstanding properties associated with the novel $\mathrm{Ag} / \mathrm{AgCl} / \mathrm{BiOIO}_{3}$ composite materials suggest that they can be used as visible-light harvesting photocatalysts for air purification applications.

\section{Experimental}

\subsection{Materials and synthesis}

All the chemicals were of analytical reagent grade and were used without further purification. $\mathrm{BiOIO}_{3}$ was obtained by a simple hydrothermal method [37]. In a typical synthesis, 0.485 g of $\mathrm{Bi}\left(\mathrm{NO}_{3}\right)_{3} \cdot 5 \mathrm{H}_{2} \mathrm{O}$ was added to $70 \mathrm{~mL}$ distilled water and stirred vigorously for $30 \mathrm{~min}$. Then, $0.214 \mathrm{~g}$ of $\mathrm{KIO}_{3}$ was added into the above aqueous solution and stirred continuously for 10 min. The resulting suspension was then hydrothermally treated at $150{ }^{\circ} \mathrm{C}$ for $6 \mathrm{~h}$. Finally, the $\mathrm{BiOIO}_{3}$ product was collected and dried at $60{ }^{\circ} \mathrm{C}$ for $12 \mathrm{~h}$.

$\mathrm{Ag} / \mathrm{AgCl} / \mathrm{BiOIO}_{3}$ nanocomposites were synthesized by a chemical precipitation method at room temperature. A certain amount of $\mathrm{NaCl}$ was dissolved in $80 \mathrm{~mL} \mathrm{H}_{2} \mathrm{O}$, and $0.48 \mathrm{~g}$ of $\mathrm{Bi}-$ $\mathrm{OIO}_{3}(1.2 \mathrm{mmol})$ was added into the above aqueous solution and stirred for $30 \mathrm{~min}$. Then, $30 \mathrm{~mL}$ aqueous solution containing $\mathrm{AgNO}_{3}$ (equal molar amount to $\mathrm{NaCl}$ ) was added dropwise into the above solution and stirred for $2 \mathrm{~h}$. After the stirring was completed, the resulting suspension was aged for $1 \mathrm{~h}$. Fi- nally, the resulting products were collected by filtration, washed with water and ethanol four times and dried at $60^{\circ} \mathrm{C}$ to obtain the final products. Depending on the molar ratio of $\mathrm{Bi}$ $\mathrm{OIO}_{3}$ to $\mathrm{NaCl}(6: 1,3: 1,1: 1,1: 3$, and 1:6), different composites can be synthesized. $\mathrm{Ag} / \mathrm{AgCl}$ was synthesized by a chemical precipitation method at room temperature without adding $\mathrm{BiOIO}_{3}$, and Ag metal was produced by photoreduction from the surrounding light.

\subsection{Characterization}

The crystal phases of the samples were analyzed by X-ray diffraction (XRD) with $\mathrm{Cu} K_{\alpha}$ radiation (model D/max RA, Rigaku Co., Japan). Scanning electron microscopy (SEM; model JSM-6490, JEOL, Japan) was used to characterize the morphology of the obtained products. The morphology and structure of the samples were examined by transmission electron microscopy (TEM; JEM-2010, JEOL, Japan). X-ray photoelectron spectroscopy (XPS) with $\mathrm{Al} K_{\alpha}$ X-rays ( $h v=1486.6 \mathrm{eV}$ ) radiation operated at $150 \mathrm{~W}$ (Thermo ESCALAB 250, USA) was used to investigate the surface properties. The UV-vis diffuse-reflectance spectrometry (DRS) spectra were obtained for the dry-pressed disk samples using a scanning UV-vis spectrophotometer (TU-1901, China) equipped with an integrating sphere assembly, using $100 \% \mathrm{BaSO}_{4}$ as the reflectance sample. $\mathrm{N}_{2}$ adsorption-desorption isotherms were obtained on $\mathrm{N}_{2}$ adsorption apparatus (ASAP 2020, Micromeritics, USA). All the samples were degassed at $100{ }^{\circ} \mathrm{C}$ prior to measurements. The photocurrent response and electrochemical impedance spectra measurements were performed in three-electrode quartz cells with a $0.1 \mathrm{~mol} / \mathrm{L} \mathrm{Na}_{2} \mathrm{SO}_{4}$ electrolyte solution. Platinum wire was used as the counter electrode, and saturated calomel electrodes were used as the reference electrodes. The as-prepared samples film electrodes on ITO served as the working electrode. The photoelectrochemical experiment results were recorded using an electrochemical system (CHI-660B, China). All the photoelectrochemical measurements were performed under visible light of a $500 \mathrm{~W}$ Xe lamp coupled with $420 \mathrm{~nm}$ cutoff filters with average light power of $45 \mathrm{~mW} / \mathrm{cm}^{2}$.

\subsection{Evaluation of photocatalytic activity}

The photocatalytic activity was investigated by removal of NO at ppb levels in a continuous flow reactor at ambient temperature. The volume of the rectangular reactor, made of polymeric glass and covered with Saint-Glass, was $4.5 \mathrm{~L}(30 \mathrm{~cm} \times$ $15 \mathrm{~cm} \times 10 \mathrm{~cm}$ ). For the visible-light photocatalytic activity test, a $150-W$ commercial tungsten halogen lamp was vertically placed outside the reactor, and a UV cut-off filter $(420 \mathrm{~nm})$ was adopted. The as-prepared sample $(0.20 \mathrm{~g})$ was dispersed in distilled water $(50 \mathrm{~mL})$ in a beaker by ultrasonic treatment for $10 \mathrm{~min}$, coated onto two glass dishes $(12.0 \mathrm{~cm}$ in diameter $)$ and then pre-treated at $70{ }^{\circ} \mathrm{C}$ to remove the water. The NO gas was acquired from a compressed gas cylinder at a concentration of $100 \mathrm{ppm}$ of NO ( $\mathrm{N}_{2}$ balance). The initial concentration of NO was diluted to about 550 ppb by the air stream supplied by a zero air generator. The desired relative humidity (RH) level of 
the NO flow was controlled at $50 \%$ by passing the zero air stream through a humidification chamber. The flow rates of the air stream and NO were controlled at $2.4 \mathrm{~L} / \mathrm{min}$ and 15 $\mathrm{mL} / \mathrm{min}$, respectively. After the adsorption-desorption equilibrium was achieved in the dark, the lamp was turned on. The concentration of NO was continuously measured by a chemiluminescence NO analyzer (Thermo Environmental Instruments Inc., model 42c-TL), which monitors $\mathrm{NO}, \mathrm{NO}_{2}$, and $\mathrm{NO}_{x}$ $\left(\mathrm{NO}_{x}\right.$ represents $\left.\mathrm{NO}+\mathrm{NO}_{2}\right)$ with a sampling rate of $1.0 \mathrm{~L} / \mathrm{min}$. The removal ratio $(\eta)$ of $\mathrm{NO}$ was calculated as $\eta=\left(1-c / c_{0}\right)$ $\times 100 \%$, where $c$ and $c_{0}$ are the concentrations of NO in the outlet steam and the feeding stream, respectively.

\section{Results and discussion}

\subsection{Structure and composition}

The crystallographic structures of $\mathrm{BiOIO}_{3}, \mathrm{Ag} / \mathrm{AgCl}$, and the $\mathrm{Ag} / \mathrm{AgCl} / \mathrm{BiOIO}_{3}$ ternary composites were characterized by $\mathrm{XRD}$, as shown in Fig. 1(a). All the peaks for the as-prepared $\mathrm{BiOIO}_{3}$ and $\mathrm{Ag} / \mathrm{AgCl}$ are indexed to the orthorhombic phase of $\mathrm{BiOIO}_{3}$ (ICSD \#262019) and cubic phase of AgCl (JCPDS 31$1238)$, respectively. In the composites, the peaks at $2 \theta=27.82^{\circ}$, $32.24^{\circ}$, and $46.25^{\circ}$, which are assigned to the (111), (200), and (220) planes of $\mathrm{AgCl}$, are detected, and the intensity of these peaks becomes stronger with the increased molar ratio of $\mathrm{NaCl}$ to $\mathrm{BiOIO}_{3}$. In contrast, the diffraction peaks attributed to $\mathrm{BiOIO}_{3}$ gradually decrease as the amount of $\mathrm{BiOIO}_{3}$ is reduced in the composites. Notably, there are no XRD peaks about $\mathrm{Ag}^{0}$ observed in the as-prepared $\mathrm{Ag} / \mathrm{AgCl}$ and ternary composites mainly because of the low content and high dispersity of $\mathrm{Ag}^{0}$. Moreover, from the enlarged view (Fig. 1(b)), the diffraction peak positions of $\mathrm{BiOIO}_{3}$ in the composites experience shifts, demonstrating that strong interactions exist between the introduced $\mathrm{Ag} / \mathrm{AgCl}$ and $\mathrm{BiOIO}_{3}$.

XPS was further used to investigate the composition of $\mathrm{Ag} / \mathrm{AgCl}$ and the ternary composites photocatalyst (1:3). As shown in Fig. 2(a), all peaks can be indexed to $\mathrm{Ag}, \mathrm{Cl}, \mathrm{O}$, and $\mathrm{C}$ elements, and no peaks of other elements are observed for $\mathrm{Ag} / \mathrm{AgCl}$. The $\mathrm{C}$ peak is mainly derived from the adventitious carbon from the XPS instrument, and the 0 peak is attributed to the surface adsorbed $\mathrm{H}_{2} \mathrm{O}$. For the ternary composite (1:3), besides the $\mathrm{C}$ peak, peaks arising from $\mathrm{Bi}, \mathrm{O}, \mathrm{I}, \mathrm{Cl}$, and $\mathrm{Ag}$ elements are observed. Fig. 2(b) shows the high-resolution XPS spectra of Bi $4 f$, and the peaks located at 159.0 and $164.4 \mathrm{eV}$ are ascribed to $\mathrm{Bi} 4 f_{7 / 2}$ and $\mathrm{Bi} 4 f_{5 / 2}$ of $\mathrm{Bi}^{3+}$, respectively [33]. The 0 $1 s$ peaks at 530.1 and $532.2 \mathrm{eV}$ in Fig. 2(c) are attributed to the $\mathrm{Bi}-\mathrm{O}$ bonds and the $\mathrm{O}-\mathrm{H}$ bonds of the surface adsorbed water, respectively. The binding energies of I $3 d_{5 / 2}$ and I $3 d_{3 / 2}$ of $\mathrm{I}^{5+}$ are 623.8 and $635.3 \mathrm{eV}$ (Fig. 2(d)) [33]. In the $\mathrm{Ag} / \mathrm{AgCl}$ sample (Fig. 2(e)), the $\mathrm{Ag} 3 d$ spectrum consists of two peaks at about 367.80 and $373.8 \mathrm{eV}$, which can be assigned to $\mathrm{Ag} 3 d_{5 / 2}$ and $\mathrm{Ag}$ $3 d_{3 / 2}$ of $\mathrm{Ag}^{+}$, respectively. Moreover, the two peaks at 368.5 and $374.7 \mathrm{eV}$, corresponding to metallic Ag, are observed, suggesting that partial $\mathrm{Ag}^{+}$ions are reduced to $\mathrm{Ag}^{0}$ [39]. Thus, the as-prepared $\mathrm{Ag} / \mathrm{AgCl}$ does contain some metallic $\mathrm{Ag}$, which mainly results from the photoreduction by the surrounding light. For the ternary composite (1:3), peaks of both $\mathrm{Ag}^{+}$and $\mathrm{Ag}^{0}$ can be detected. In terms of $\mathrm{Cl} 2 p$ (Fig. 2f), the binding energies of $\mathrm{Cl} 2 p_{3 / 2}$ and $\mathrm{Cl} 2 p_{1 / 2}$ are approximately 198.3 and $199.9 \mathrm{eV}$, respectively, which are detected in $\mathrm{Ag} / \mathrm{AgCl}$ and the composite (1:3). It can be seen that the peaks of $\mathrm{Ag}^{0}, \mathrm{Ag}^{+}$, and $\mathrm{Cl}^{-}$undergo chemical shifts in the composite $(1: 3)$ relative to those of $\mathrm{Ag} / \mathrm{AgCl}$, indicating the presence of strong interactions among the three components, which is consistent with the XRD result. The XPS results suggest the successful coupling of
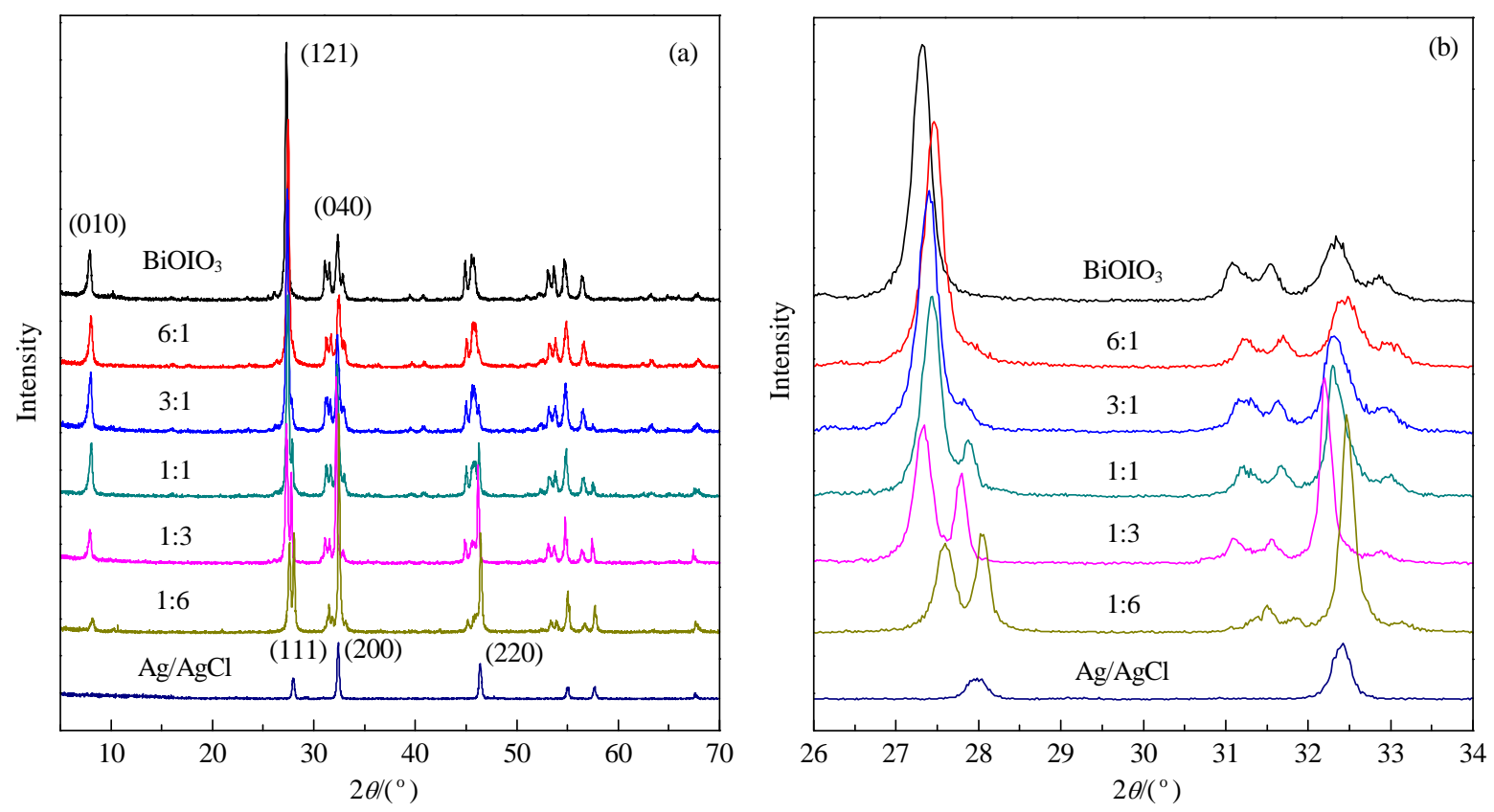

Fig. 1. XRD patterns (a) and enlarged view of $2 \theta=26^{\circ}-34^{\circ}$ diffraction region (b) of $\mathrm{BiOIO}_{3}, \mathrm{Ag} / \mathrm{AgCl}$, and the $\mathrm{Ag} / \mathrm{AgCl} / \mathrm{BiOIO}{ }_{3}$ ternary composites prepared using different $\mathrm{BOIO}_{3}$ to $\mathrm{NaCl}$ molar ratios. 

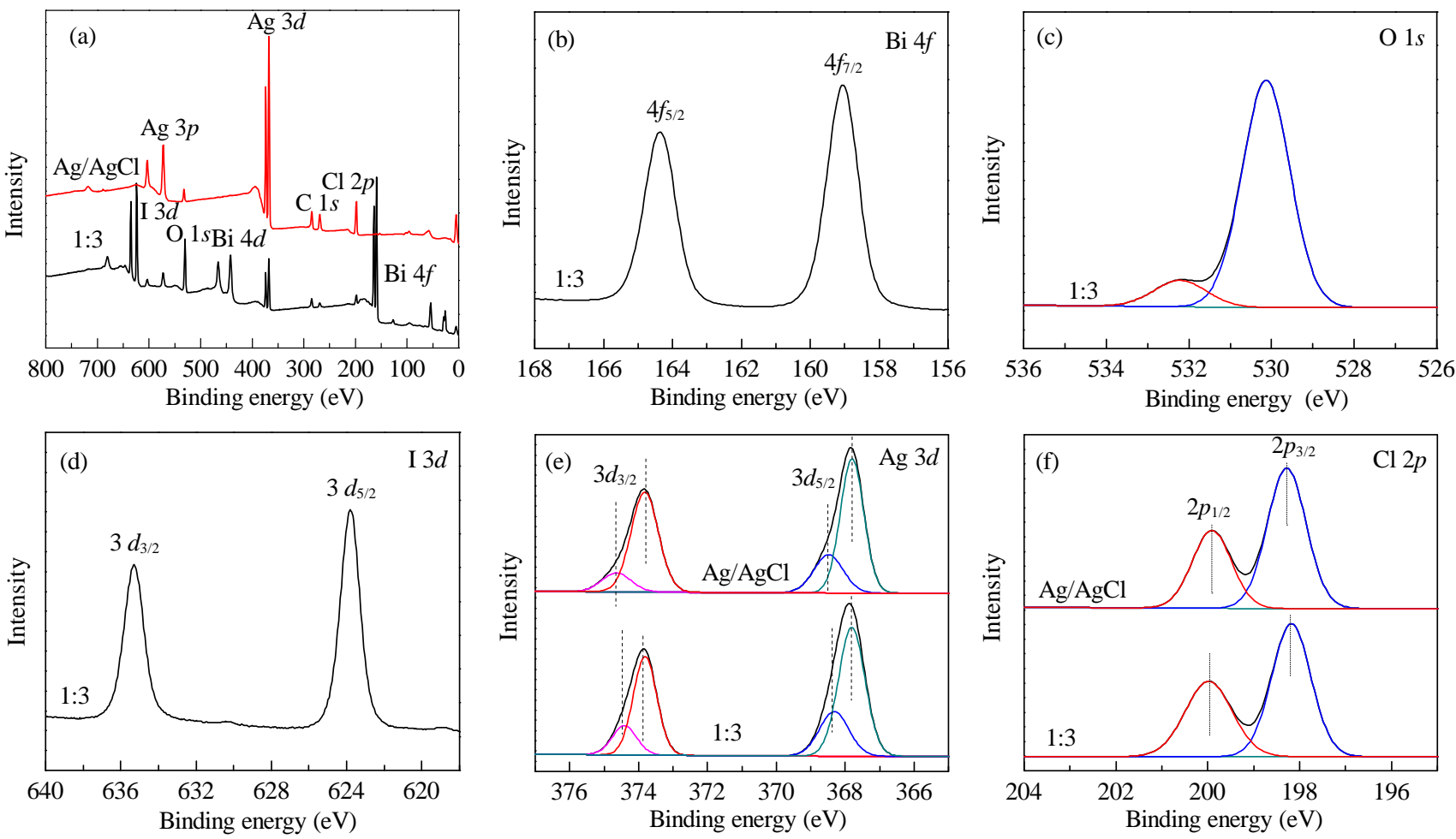

Fig. 2. XPS spectra of $\mathrm{Ag} / \mathrm{AgCl}$ and the $\mathrm{Ag} / \mathrm{AgCl} / \mathrm{BiOIO}_{3}$ ternary composite (1:3). (a) Survey spectra; (b) $\mathrm{Bi} 4 f$; (c) $01 s$; (d) I 3d; (e) $\mathrm{Ag} 3 d$; (f) $\mathrm{Cl} 2 p$.

$\mathrm{Ag} / \mathrm{AgCl}$ with $\mathrm{BiOIO}_{3}$.

\subsection{Morphology}

The morphology of $\mathrm{Ag} / \mathrm{AgCl}, \mathrm{BiOIO}_{3}$, and the composite (1:3) were investigated by SEM and TEM. As shown in Fig. 3(a) and (b), particle-like $\mathrm{AgCl}$ can be observed, while pure $\mathrm{BiOIO}_{3}$ is mainly composed of nanosheets, as revealed by Fig. 3(c) and (d). In the composite (1:3), particle-like $\mathrm{AgCl}$ and nanosheetshaped $\mathrm{BiOIO}_{3}$ can be observed (Fig. 3(e) and (f)), implying that the shapes of $\mathrm{BiOIO}_{3}$ and $\mathrm{Ag} / \mathrm{AgCl}$ do not show significant changes after compositing. The TEM image further confirms that the composites have two morphologies, as particles and nanosheets (Fig. 3(g)). From the HRTEM image (Fig. 3(h)), the distance between the two adjacent planes is $0.37 \mathrm{~nm}$, corresponding to the (111) plane of $\mathrm{BiOIO}_{3}$, and the distance of 0.32 $\mathrm{nm}$ belongs to the (111) plane of $\mathrm{AgCl}$. As can be seen, the intimate interfacial contact exists in these components, which is beneficial for charge separation and transfer.

\subsection{Optical properties}

The optical properties of the as-obtained samples were characterized by UV-vis DRS spectra and the results are shown in Fig. 4. $\mathrm{BiOIO}_{3}$ has a clear edge around $390 \mathrm{~nm}$, and no significant absorption in the visible-light region is observed. The
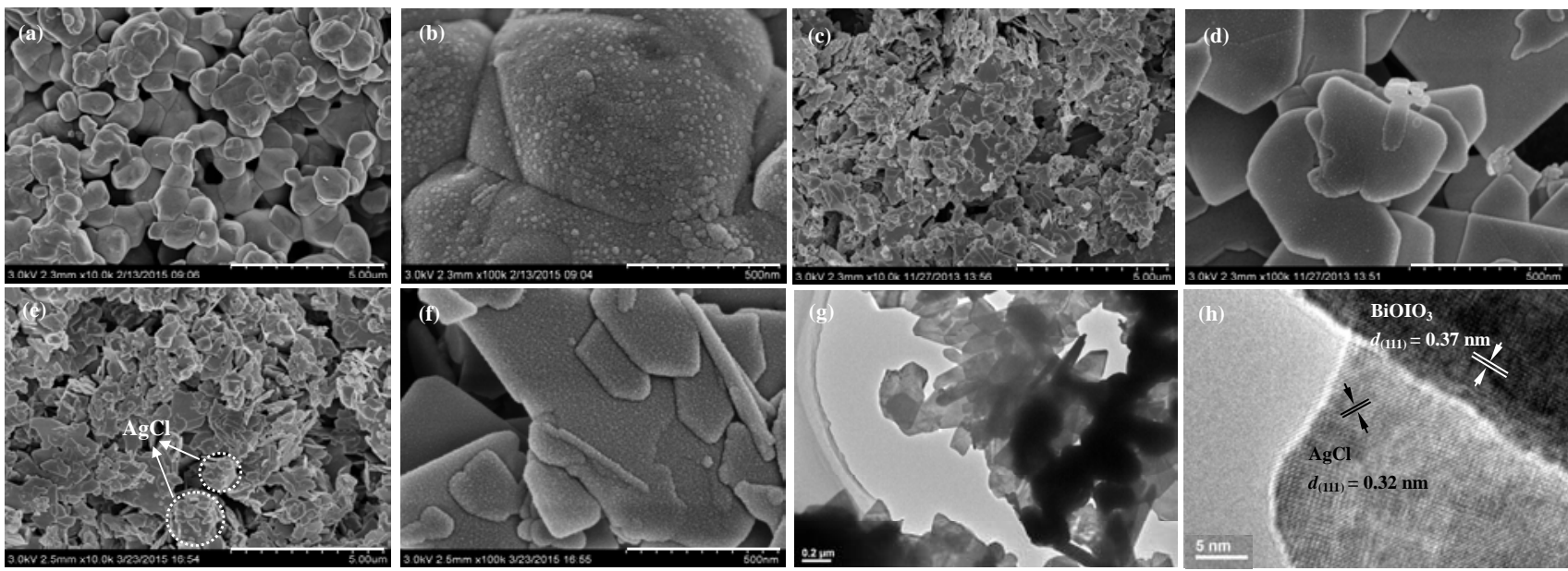

Fig. 3. SEM images of $\mathrm{Ag} / \mathrm{AgCl}(\mathrm{a}, \mathrm{b}), \mathrm{BiOIO}_{3}(\mathrm{c}, \mathrm{d})$, and the ternary composite (1:3) (e, f); TEM and HRTEM images of the ternary composite (1:3) (g, h). 


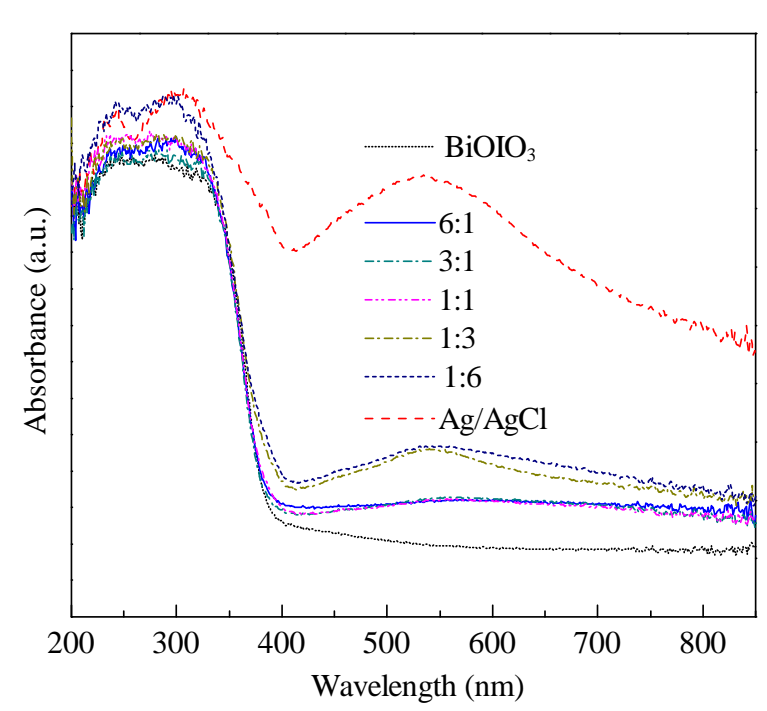

Fig. 4. UV-vis DRS spectra of the as-prepared samples.

bandgap of $\mathrm{BiOIO}_{3}$ is $3.1 \mathrm{eV}$ [37]. The $\mathrm{Ag} / \mathrm{AgCl}$ sample exhibits a wide and strong light absorption centered at $545 \mathrm{~nm}$, and this strong visible-light absorption can be attributed to the strong plasmon resonance absorption of Ag particles [40-42]. After construction of the ternary composites, none of the composites show an obvious enhanced absorption in the ultraviolet-light region in contrast to the pure $\mathrm{BiOIO}_{3}$, but display a boost in the visible-light absorption. The absorption intensity in the visible-light region continually increases as the molar ratio of $\mathrm{Bi}$ $\mathrm{OIO}_{3}$ to $\mathrm{NaCl}$ is increased. The enhanced visible-light absorption can be ascribed to the plasmon resonance absorption of Ag particles. It can be concluded that the introduction of $\mathrm{Ag} / \mathrm{AgCl}$ into $\mathrm{BiOIO}_{3}$ benefits the optical absorption property and the usage efficiency of visible light. Similar phenomena are also observed in the cases of $\mathrm{Ag} / \mathrm{AgCl} / \mathrm{TiO}_{2}$ and $\mathrm{Ag} / \mathrm{AgCl} / \mathrm{WO}_{3}$ $[20,22]$. The remarkable absorption enhancement in the visible region is beneficial to improve the photocatalytic performance.

\subsection{Charge separation}

Photoelectrochemical measurements were performed to investigate the excitation, separation, transfer, and recombina- tion of photoinduced charge carriers [43]. Fig. 5(a) shows the photocurrent of the samples irradiated under visible light. Obviously, the enhanced photocurrent is observed in the ternary composites, implying an enhanced separation efficiency of photoinduced electrons and holes [44]. The typical electrochemical impedance spectra (EIS) were adopted to investigate the photogenerated charge separation process, as shown in Fig. 5(b). It is observed that with the addition of $\mathrm{Ag} / \mathrm{AgCl}$, although in a small amount, the diameters of the arc radius on the EIS Nyquist plot of the ternary composites are smaller than those of pure $\mathrm{BiOIO}_{3}$, which reveals a decrease in the interface layer resistance and the charge transfer resistance on the surface. Among these composites, the composite (1:6) shows the strongest photocurrent and the most efficient separation ability of charge carriers. Overall, charge transfer is accelerated and charge recombination is suppressed owing to the interfacial interaction between the $\mathrm{Ag} / \mathrm{AgCl}$ and $\mathrm{BiOIO}_{3}$. Thereby, a high efficiency in photocatalysis over the ternary composites would be achieved.

\subsection{Pore structures}

The $\mathrm{N}_{2}$ adsorption-desorption isotherms of all the prepared photocatalysts are shown in Fig. 6(a). From the isotherms, the $\mathrm{Ag} / \mathrm{AgCl}$ sample displays the type III (Brunauer-Deming-Deming-Teller classification) isotherm, which characteristically indicates a weak interaction existing between $\mathrm{N}_{2}$ and the sample. However, it is observed that the other samples show type IV isotherms with H3 hysteresis loops [45]. In view of the morphological structure, the H3 hysteresis loops might arise from the aggregation of nanosheet-like particles possessing slit-shaped pores. Fig. 6(b) displays the corresponding pore-size distributions. No pores exist in $\mathrm{Ag} / \mathrm{AgCl}$. The composites, as well as pure $\mathrm{BiOIO}_{3}$, contain macropores and large mesopores over a broad range with the peaks centered at approximately $50 \mathrm{~nm}$. These results demonstrate the formation of hierarchically nanoporous structures. The BET surface areas of $\mathrm{Ag} / \mathrm{AgCl}, \mathrm{BiOIO}_{3}$, and the composites (6:1), (3:1), (1:1), (1:3), and (1:6) are calculated to be $1,14,10,10,8.5,4.8$, and $5 \mathrm{~m}^{2} / \mathrm{g}$, respectively. It is clear that the specific surface areas of these photocatalysts are relatively low.
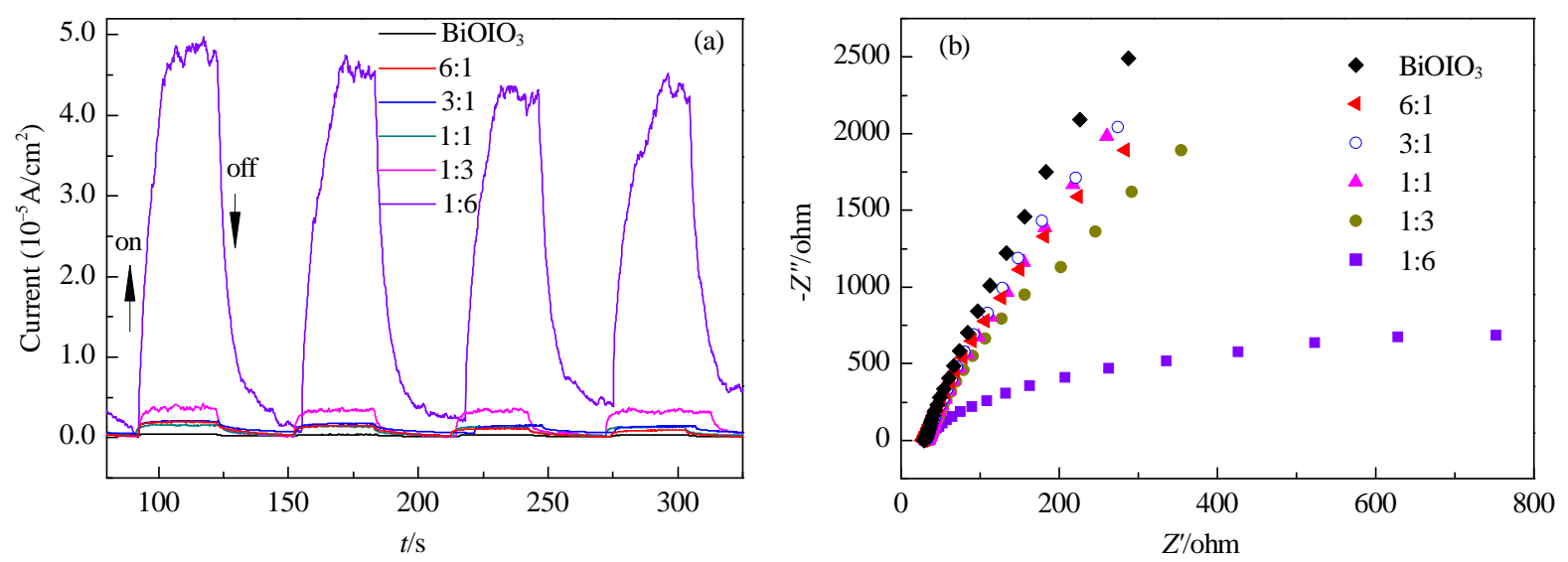

Fig. 5. Transient photocurrent response (a) and electrochemical impedance spectroscopy Nyquist plots (b) of $\mathrm{BiOIO}_{3}$ and the ternary composites. 

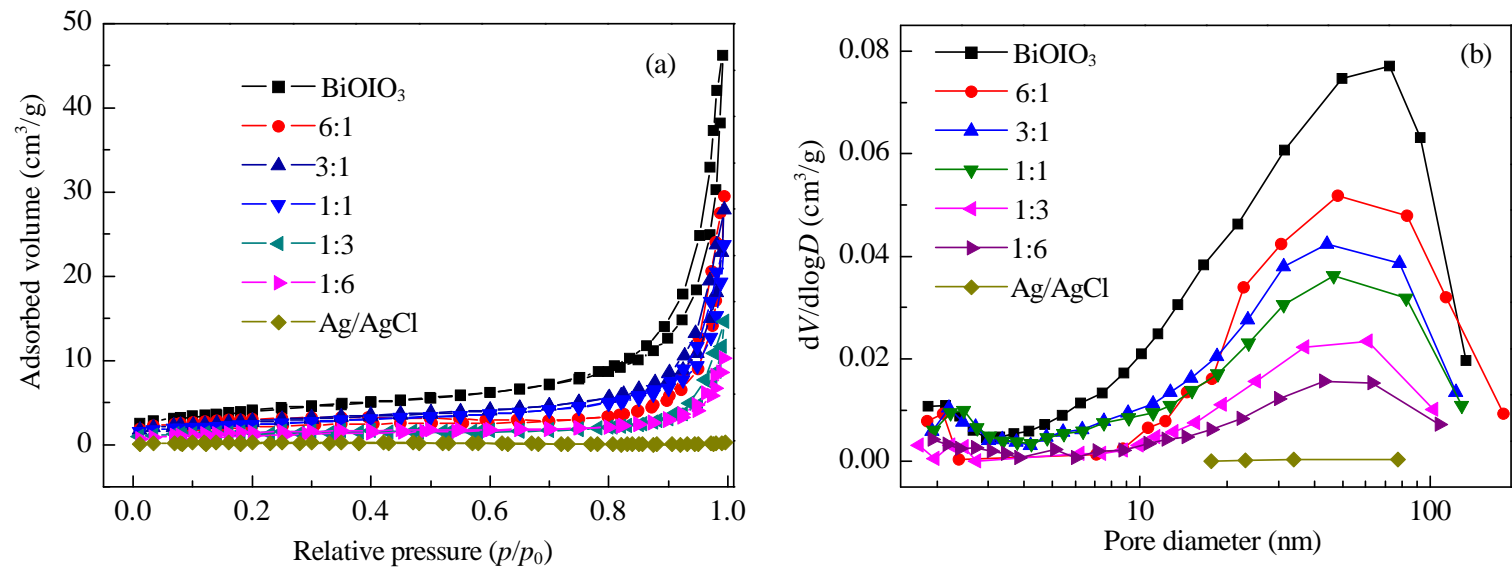

Fig. 6. $\mathrm{N}_{2}$ adsorption-desorption isotherms curves (a) and pore-size distribution (b) of the as-prepared samples.

\subsection{Photocatalytic activity and mechanism}

The as-synthesized ternary samples show high visible absorption and efficient charge transfer, so they are expected to show high visible-light photocatalytic activity. NO, which is chemically stable and hard to remove, was chosen as the representative air pollutant to evaluate the photocatalytic performance of the as-synthesized photocatalysts. Fig. 7(a) shows the photocatalytic activity of the seven photocatalysts. $\mathrm{BiOIO}_{3} \mathrm{ex}-$ hibits poor photocatalytic activity with a removal ratio of $13.0 \%$ owing to its large bandgap. The as-prepared $\mathrm{Ag} / \mathrm{AgCl}$
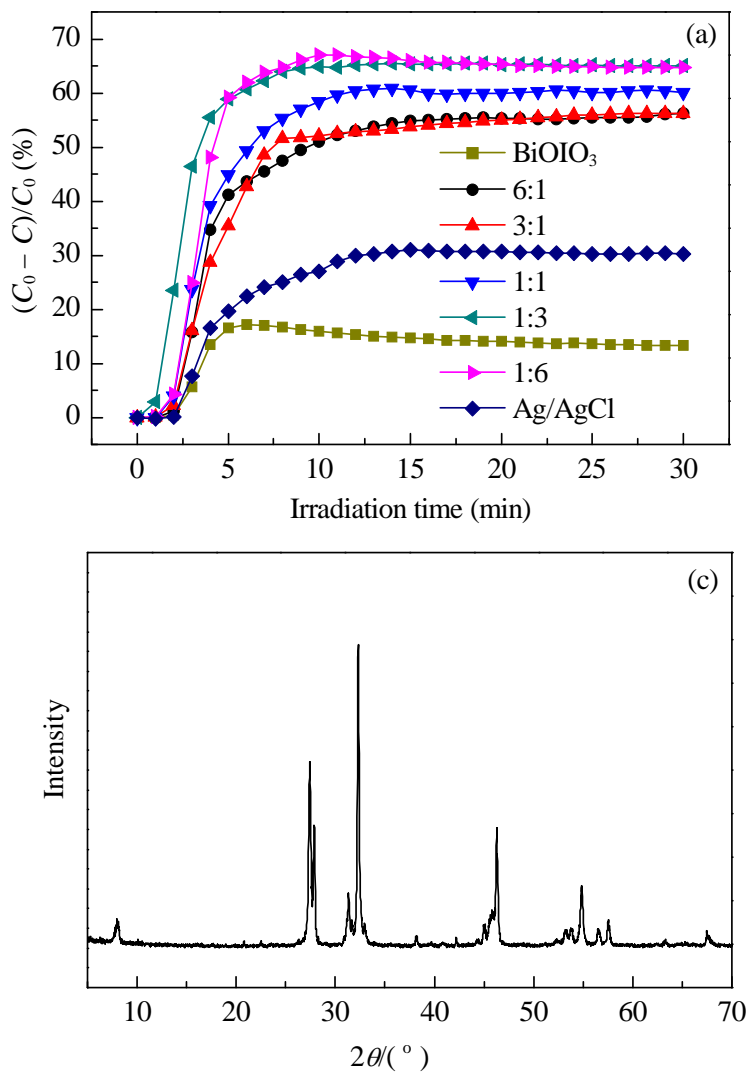

sample shows a certain photocatalytic performance (removal ratio of ca. 30\%) because of the existence of $\mathrm{Ag}^{0}$. Metal $\mathrm{Ag}$ with plasmon resonance effects can be excited by visible light to generate carriers, and electrons can react with the species at the interfaces while holes inject into the nearby $\mathrm{AgCl}$ to oxidize $\mathrm{Cl}^{-}$ions to yield $\mathrm{Cl}$ atoms, which are reactive for oxidizing species in the surrounding environment. Meanwhile, $\mathrm{Cl}$ atoms would be reduced back to $\mathrm{Cl}^{-}$after redox reactions [40,41]. With the assistance of composite photocatalysts, the high visible-light photocatalytic activity is obviously superior to those observed from the $\mathrm{BiOIO}_{3}$ and $\mathrm{Ag} / \mathrm{AgCl}$. Adding a small amount of $\mathrm{Ag} / \mathrm{AgCl}$ can result in significantly increased photocatalytic
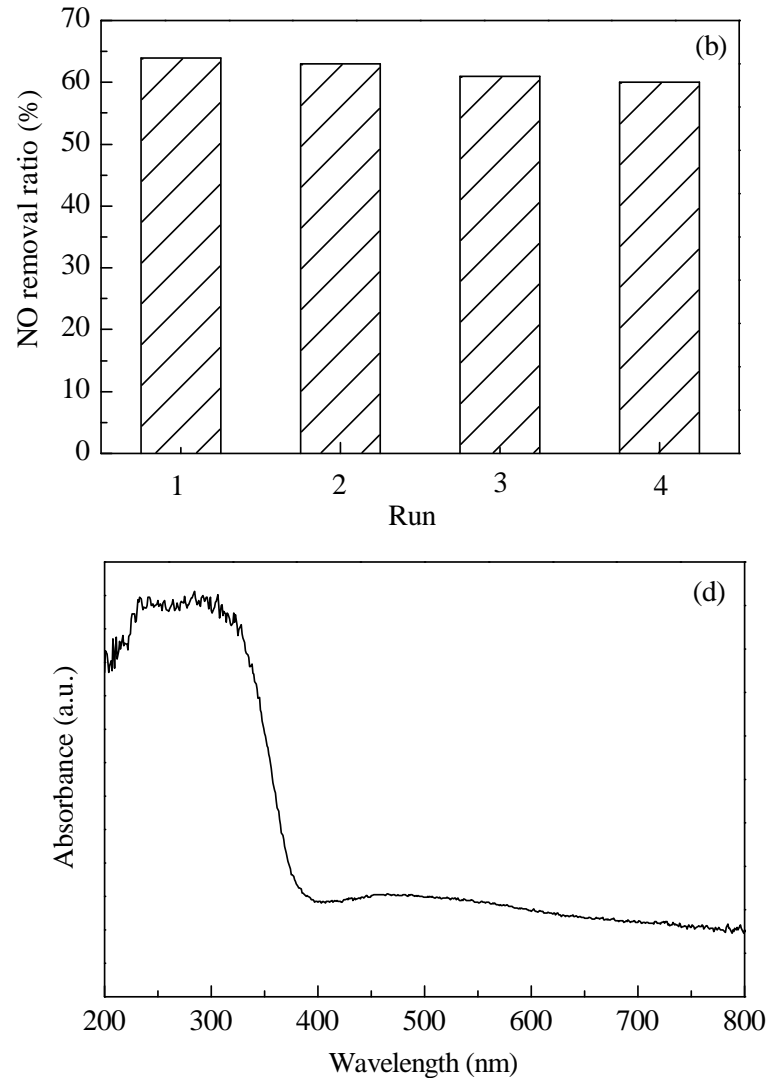

Fig. 7. Photocatalytic oxidation of NO over the as-prepared samples (a), cycling runs of the composite (1:3) in air under visible-light irradiation (b), and XRD pattern (c) and UV-vis DRS spectrum (d) of the composite (1:3) after cycling testing. 


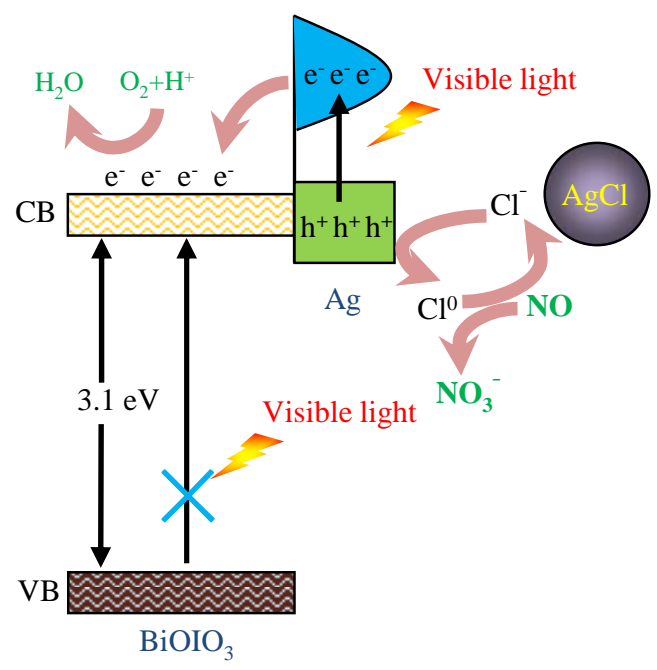

Fig. 8. Proposed photocatalytic mechanism of the as-prepared ternary composites.

activity. The composite (6:1) displays a high removal ratio of $56.0 \%$. With an increased $\mathrm{Ag} / \mathrm{AgCl}$ content in the composites, the NO removal ratio gradually increases and finally reaches a stable value. The composites (1:3) and (1:6) show a comparable and high removal ratio of approximately $64.0 \%$ for the removal of NO. To evaluate the stability of the photocatalytic performance of the composite (1:3), circulating runs were carried out. As shown in Fig. 7(b), the composite (1:3) shows a slight decrease in activity after four recycles, which can be attributed to the products or intermediates blocking the active sites. Furthermore, XRD, combined with the UV-vis DRS spectra, reflects the good stability in the phase structure and light absorption properties of the composite (1:3) (Fig. 7(c) and (d)).

Based on the previously reported photocatalyst systems, such as $\mathrm{Ag} / \mathrm{AgCl} / \mathrm{TiO}_{2}, \mathrm{Ag} @ \mathrm{AgCl}$, and the above experimental results $[20,40]$, the photocatalytic mechanism of the $\mathrm{Ag} / \mathrm{AgCl} / \mathrm{BiOIO}_{3}$ system is proposed, as depicted in Fig. 8. Under visible-light irradiation, photogenerated electron-hole pairs are created in Ag particles owing to surface plasmon resonance. A Schottky barrier is formed at the $\mathrm{Ag} / \mathrm{BiOIO}_{3}$ interface owing to the different work functions. As the plasmon-induced electrons of Ag particles can transfer to the conduction band $(-0.2$ $\mathrm{V}$ vs NHE) of $\mathrm{TiO}_{2}$ under visible-light irradiation [46], it is believed that the photo-induced electrons of $\mathrm{Ag}$ particles can easily transfer to the conduction band $(+0.99 \mathrm{~V}$ vs $\mathrm{NHE})$ of $\mathrm{BiOIO}_{3}$ [37]. The potential of the electrons on the conduction band of $\mathrm{BiOIO}_{3}$ are not negative enough to induce the generation of $\cdot \mathrm{O}_{2}{ }^{-}$. Alternatively, electrons can be consumed by multi-electrons reactions to yield $\mathrm{H}_{2} \mathrm{O}$ [47]. Meanwhile, the holes left on the surface of Ag particles can transfer to the surface of $\mathrm{AgCl}$ to oxidize $\mathrm{Cl}^{-}$to $\mathrm{Cl}^{0}$. The light irradiation induces reduction of partial $\mathrm{Ag}^{+}$ions and leaves $\mathrm{Cl}^{-}$ions, so that the surface of $\mathrm{AgCl}$ particles is negatively charged and terminated by $\mathrm{Cl}^{-}$ions. $\mathrm{Cl}^{0}$ atoms are reactive radical species, which are able to oxidize $\mathrm{NO}$ and then be reduced to $\mathrm{Cl}^{-}$again. In this case, $\mathrm{BiOIO}_{3}$ contributes to the rapid transfer of photogenerated electrons, leading to a lower recombination rate and enhanced photocatalytic activity.

\section{Conclusions}

$\mathrm{Ag} / \mathrm{AgCl} / \mathrm{BiOIO}_{3}$ was constructed through a two-step synthesis route. The generation of $\mathrm{AgCl}$ was accompanied with the in situ formation of metallic $\mathrm{Ag}$ by photoreduction of $\mathrm{Ag}^{+}$ions by the surrounding light. Remarkable improvement of NO removal capability for $\mathrm{Ag} / \mathrm{AgCl} / \mathrm{BiOIO}_{3}$ was a result of the enhanced visible-light harvesting and decreased recombination of photogenerated electron-hole pairs owing to the strong interaction of $\mathrm{Ag} / \mathrm{AgCl}$ and $\mathrm{BiOIO}_{3}$. This originated from the surface plasmon resonance absorption of $\mathrm{Ag}$ particles under visible-light irradiation and the charge separation at $\mathrm{Ag} / \mathrm{BiOIO}_{3}$ surface, which included electrons transferring from the photo-excited $\mathrm{Ag}$ to $\mathrm{BiOIO}_{3}$ and holes transferred to $\mathrm{AgCl}$ to oxidize $\mathrm{Cl}^{-}$. The present work provides fundamental insights into the role of $\mathrm{BiOIO}_{3}$ in tuning interfacial charge transfer processes. The highly efficient $\mathrm{Ag} / \mathrm{AgCl} / \mathrm{BiOIO}_{3}$ composites are widely applicable in various fields, such as air purification and waste water treatment.

\section{References}

[1] Kapilashrami M, Zhang Y F, Liu Y S, Hagfeldt A, Guo J H. Chem Rev, 2014, 114: 9662

[2] Mo J H, Zhang Y P, Xu Q J, Lamson J, Zhao R Y. Atmos Environ, 2009, 43: 2229

[3] Zheng Y, Liu J, Liang J, Jaroniec M, Qiao S Z. Energy Environ Sci, 2012, 5: 6717

[4] Naldoni A, Allieta M, Santangelo S, Marelli M, Fabbri F, Cappelli S, Bianchi C L, Psaro R, Santo V D. J Am Chem Soc, 2012, 134: 7600

[5] Liu G, Yang H G, Wang X W, Cheng L N, Pan J, Lu G Q, Cheng H M. J Am Chem Soc, 2009, 131: 12868

[6] Li R G, Zhang F X, Wang D E, Yang J X, Li M R, Zhu J, Zhou X, Han H X, Li C. Nat Commun, 2013, 4: 1432

[7] Zhu S Y, Liang S J, Gu Q, Xie L Y, Wang J X, Ding Z X, Liu P. Appl Catal B, 2012, 119-120: 146

[8] Asahi R, Morikawa T, Irie H, Ohwaki T. Chem Rev, 2014, 114: 9824

[9] Bian Z F, Tachikawa T, Zhang P, Fujitsuka M, Majima T. J Am Chem Soc, 2014, 136: 458

[10] Liu M, Inde R, Nishikawa M, Qiu X Q, Atarashi D, Sakai E, Nosaka Y, Hashimoto K, Miyauchi M. ACS Nano, 2014, 8: 7229

[11] Subash B, Krishnakumar B, Swaminathan M, Shanthi M. Langmuir, 2013, 29: 939

[12] Bai X J, Sun C P, Wu S L, Zhu Y F. J Mater Chem A, 2015, 3: 2741

[13] Dong F, Zhao Z W, Xiong T, Ni Z L, Zhang W D, Sun Y J, Ho W K. ACS Appl Mater Interface, 2013, 5: 11392

[14] Yu C L, Zhou W Q, Yu J C, Liu H, Wei F L. Chin J Catal (余长林, 周晚 琴, 余济美, 刘鸿, 魏龙福. 催化学报), 2014, 35: 1609

[15] Yu J G, Wang S H, Low J X, Xiao W. Phys Chem Chem Phys, 2013, 15: 16883

[16] Zhao Z W, Sun Y J, Dong F. Nanoscale, 2015, 7: 15

[17] Hou Y, Li X Y, Zhao Q D, Chen G H, Raston C L. Environ Sci Technol, 2012, 46: 4042

[18] Hu X X, Hu C, Peng T W, Zhou X F, Qu J H. Environ Sci Technol, 2010, 44: 7058

[19] Zhou Z J, Long M C, Cai W M, Cai J. J Mol Catal A, 2012, 353-354: 22

[20] Yu J G, Dai G P, Huang B B.J Phys Chem C, 2009, 113: 16394

[21] Zhang J, Niu C G, Ke J, Zhou L F, Zeng G M. Catal Commun, 2015, 59: 30

[22] Ma B W, Guo J F, Dai W L, Fan K N. Appl Catal B, 2012, 123-124: 


\title{
Graphical Abstract
}

Chin. J. Catal., 2015, 36: 2155-2163 doi: 10.1016/S1872-2067(15)60980-9

Ternary $\mathrm{Ag} / \mathrm{AgCl} / \mathrm{BiOIO}_{3}$ composites for enhanced visible-light-driven photocatalysis

Ting Xiong, Huijun Zhang, Yuxin Zhang, Fan Dong*

Chongqing Technology and Business University; Chongqing University

Ternary $\mathrm{Ag} / \mathrm{AgCl} / \mathrm{BiOIO}_{3}$ composite photocatalysts show improved activity for NO removal compared with $\mathrm{Ag} / \mathrm{AgCl}$ and pure $\mathrm{BiOIO}_{3}$. This arises from the surface plasmon resonance effects of $\mathrm{Ag}$ metal and theeffective carrier separation ability of $\mathrm{BiOIO}_{3}$.

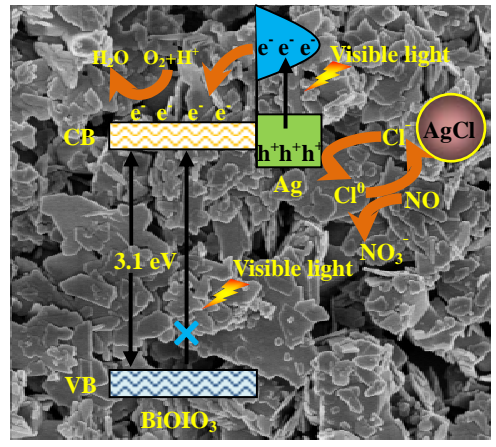

193

[23] Chen D M, Wang Z H, Ren T Z, Ding H, Yao W Q, Zong R L, Zhu Y F. J Phys Chem C, 2014, 118: 15300

[24] Schneider J, Matsuoka M, Takeuchi M, Zhang J L, Horiuchi Y, Anpo M, Bahnemann D W. Chem Rev, 2014, 114: 9919

[25] Tan H Q Zhao Z, Zhu W B, Coker E N, Li B S, Zheng M, Yu W X, Fan H Y, Sun Z C. ACS Appl Mater Interfaces, 2014, 6: 19184

[26] Manna G, Bose R, Pradhan N. Angew Chem Int Ed, 2014, 53: 6743

[27] He R A, Cao S W, Zhou P, Yu J G. Chin J Catal (赫荣安, 曹少文, 周 鹏, 余家国. 催化学报), 2014, 35: 989

[28] Zhang L W, Zhu Y F. Catal Sci Technol, 2012, 2: 694

[29] Sun S M, Wang W Z. RSC Adv, 2014, 4: 47136

[30] Li J, Yu Y, Zhang L Z. Nanoscale, 2014, 6: 8473

[31] Dong F, Ho W K, Lee S C, Wu Z B, Fu M, Zou S C, Huang Y.J Mater Chem, 2011, 21: 12428

[32] Nguyen S D, Yeon J, Kim S H, Halasyamani P S. J Am Chem Soc 2011, 133: 12422

[33] Wang W J, Huang B B, Ma X C, Wang Z Y, Qin X Y, Zhang X Y, Dai Y, Whangbo M-H. Chem Eur J, 2013, 19: 14777

[34] Huang H W, He Y, He R, Jiang X X, Lin Z S, Zhang Y H, Wang S C. Inorg Chem Commun, 2014, 40: 215

[35] Huang H W, Wang S B, Tian N, Zhang Y H. RSC Adv, 2014, 4: 5561
[36] Wang W J, Cheng H F, Huang B B, Liu X L, Qin X Y, Zhang XY, Dai Y. J Colloid Interface Sci, 2015, 442: 97

[37] Xiong T, Dong F, Zhou Y, Fu M, Ho W K. J Colloid Interface Sci, 2015, 447: 16

[38] Dong F, Xiong T, Sun Y J, Zhang Y X, Zhou Y. Chem Commun, 2015, 51: 8249

[39] Xu Y S, Zhang W D. ChemCatChem, 2013, 5: 2343

[40] Wang P, Huang B B, Qin X Y, Zhang X Y, Dai Y, Wei J Y, Whangbo M H. Angew Chem Int Ed, 2008, 47: 7931

[41] Chen D L, Yoo S H, Huang Q S, Ali G, Cho S O. Chem Eur J, 2012, 18: 5192

[42] Bai X J, Zong R L, Li C X, Liu D, Liu Y F, Zhu Y F. Appl Catal B, 2014, 147: 82

[43] Leng W H, Zhang Z, Zhang J Q, Cao C N. J Phys Chem B, 2005, 109: 15008

[44] Wang K, Li Q, Liu B S, Cheng B, Ho W, Yu J G. Appl Catal B, 2015, 176-177: 44

[45] Sing K S W, Everett D H, Haul R A W, Moscou L, Pierotti R A, Rouquerol J, Siemieniewska T. Pure Appl Chem, 1985, 57: 603

[46] Wu T S, Wang K X, Li G D, Sun S Y, Sun J, Chen J S. ACS Appl Mater Interfaces, 2010, 2: 544

[47] Kim J, Lee C W, Choi W. Environ Sci Technol, 2010, 44: 6849

\section{$\mathrm{Ag} / \mathrm{AgCl} / \mathrm{BiOIO}_{3}$ 三元复合物光催化剂的性能增强机制}

\author{
熊 婷 ${ }^{\mathrm{a}}$, 张会均 ${ }^{\mathrm{a}}$, 张育新 ${ }^{\mathrm{b}}$, 董 帆 $^{\mathrm{a},{ }^{*}}$ \\ a 重庆工商大学环境与资源学院催化与功能有机分子重庆市重点实验室, 重庆400067

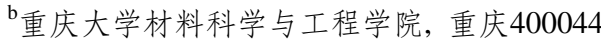

摘要: 半导体光催化技术是一种环境友好技术, 它既能在温和条件下应用于环境领域一一利用光能降解有机和无机污染物, 又可 应用于能源领域——将低密度的太阳能转化为高密度的洁净能源, 因而在解决环境污染和能源贵乏问题方面展现出巨大的应用 潜力. 最近, 一种新型 $\mathrm{Bi}$ 基光催化剂, $\mathrm{BiOIO}_{3}$, 表现出优异的紫外光催化性能. 它由层状 $\left[\mathrm{Bi}_{2} \mathrm{O}_{2}\right]^{2+}$ 和 $\left[\mathrm{IO}_{3}\right]^{-}$组装而成, 带隙为 $3.1 \mathrm{eV}$ 左 右. 然而, 其较大的带隙限制了其对太阳光的利用. 近年来,多种方法如金属掺杂、非金属掺杂、半导体复合、光敏化改性和加氢 处理被用来提高半导体的光催化效率. 其中, 以 $\mathrm{Ag} / \mathrm{AgX}(\mathrm{X}=\mathrm{Cl}, \mathrm{I}$ 和Br$)$ 作为助催化剂可提高体系的可见光吸收和载流子的分离能 力, 从而增强光催化性能. 基于此, 我们设计并合成了一种新型的三元光催化剂. 首先采用水热法合成了 $\mathrm{BiOIO}_{3}$ 纳米片,然后在室 温条件下原位引进 $\mathrm{Ag} / \mathrm{AgCl}$, 制备了 $\mathrm{Ag} / \mathrm{AgCl} / \mathrm{BiOIO}{ }_{3}$ 三元异质结构. 与 $\mathrm{Ag} / \mathrm{AgCl}$ 和纯的 $\mathrm{BiOIO}_{3}$ 相比, 该三元 $\mathrm{Ag} / \mathrm{AgCl} / \mathrm{BiOIO}_{3}$ 复合物 光催化剂对 $N O$ 表现出优异的可见光光催化去除性能.

本文采用X射线衍射(XRD)、X射线光电子能谱(XPS)、扫描式电子显微镜(SEM)、电化学测试(光电流和阻抗谱)和紫外-可见 漫反射光谱(UV-Vis)等表征手段研究了 $\mathrm{Ag} / \mathrm{AgCl} / \mathrm{BiOIO}_{3}$ 光催化性能增强的机制. $\mathrm{SEM}$ 结果表明,制备的 $\mathrm{Ag} / \mathrm{AgCl} / \mathrm{BiOIO}_{3}$ 三元复合 物为纳米颗粒和纳米片形貌, $\mathrm{Ag} / \mathrm{AgCl}$ 的引入对 $\mathrm{BiOIO}_{3}$ 形貌影响不大. $\mathrm{XRD}$ 和XPS测试结果表明, 与纯的 $\mathrm{BiOIO}_{3}$ 相比, 随着 $\mathrm{Ag} / \mathrm{AgCl}$ 
的加入, 复合物的峰位置发生了明显位移, 表明 $\mathrm{Ag}, \mathrm{AgCl}$ 和 $\mathrm{BiOIO}_{3}$ 三组分间存在强的相互作用. 光电流响应图谱表明, 随着 $\mathrm{Ag} / \mathrm{AgCl}$ 的加入, $\mathrm{Ag} / \mathrm{AgCl} / \mathrm{BiOIO}_{3}$ 的光电流强度明显增强, 同时阻抗谱的圆弧直径明显减小, 表明电子和空穴的分离能力增强. UV-Vis图谱 中, $\mathrm{BiOIO}_{3}$ 在可见光区几乎没有吸收, 而三元复合物表现出明显的可见光吸收, 且随着 $\mathrm{Ag} / \mathrm{AgCl}$ 量的增加, 复合物的可见光吸收增 强, 该吸收归结于复合物中 $\mathrm{Ag}$ 的表面等离子体吸收. 结合之前报道的光催化剂体系如 $\mathrm{Ag} / \mathrm{AgCl}$ 和 $\mathrm{Ag} / \mathrm{AgCl} / \mathrm{TiO}_{2}$, 我们提出了 $\mathrm{Ag} / \mathrm{AgCl}^{\mathrm{B}} / \mathrm{BiOIO}_{3}$ 复合物光催化剂性能增强的机制.

在可见光照射下, $\mathrm{Ag}^{0}$ 因其表面等离子体吸收而产生电子空穴对. 由于功函数不同, $\mathrm{Ag}$ 和 $\mathrm{BiOIO}_{3}$ 之间形成肖特基势垒. 电子从 $\mathrm{Ag}^{0}$ 表面转移到 $\mathrm{BiOIO}_{3}$ 的导带上, $\mathrm{BiOIO}_{3}$ 导带上电子的电势不足以把 $\mathrm{O}_{2}$ 氧化成 $\mathrm{O}_{2}{ }^{-}$, 但电子能以多电子的形式与 $\mathrm{O}_{2}$ 和 $\mathrm{H}^{+}$生成水. 同 时, $\mathrm{Ag}^{0}$ 表面的空穴能将 $\mathrm{AgCl}$ 表面的 $\mathrm{Cl}^{-}$氧化成 $\mathrm{Cl}^{0}$. 光照诱导 $\mathrm{AgCl}$ 表面的部分 $\mathrm{Ag}^{+}$离子被还原, 所以 $\mathrm{AgCl}$ 粒子的表面带负电荷. $\mathrm{Cl}^{0}$ 是活性自由基, 能够氧化去除 $\mathrm{NO}$, 反应之后自身被还原成 $\mathrm{Cl}^{-}$. 由此可见, 在三元复合光催化剂中, $\mathrm{Ag}^{0}$ 在可见光照射下因其表面等 离子体效应产生电子空穴对, 随后 $\mathrm{BiOIO}_{3}$ 有效地分离了光生载流子, 使得复合材料能有效地利用光生电子和空穴. 故三元 $\mathrm{Ag} / \mathrm{AgCl} / \mathrm{BiOIO}_{3}$ 复合物光催化剂增强的光催化性能可归结于 $\mathrm{Ag}$ 的表面等离子体吸收和 $\mathrm{BiOIO}_{3}$ 的载流子分离能力. 该结果有助于 设计和制备具有优异的光催化性能的 $\mathrm{BiOIO}_{3}$ 基材料.

关键词: 银/氯化银/碘酸氧铋; 三元复合物; 可见光催化; 一氧化氮去除; 载流子分离

收稿日期: 2015-08-21. 接受日期: 2015-09-13. 出版日期: 2015-12-20.

*通讯联系人. 电话/传真: (023)62769785-605; 电子信箱: dfctbu@126.com

基金来源: 国家自然科学基金(51478070, 51108487); 重庆市教育委员会科技项目(KJ1400617).

本文的英文电子版由Elsevier出版社在ScienceDirect上出版(http://www.sciencedirect.com/science/journal/18722067). 